\title{
Microencapsulated acids associated with essential oils and acid salts for piglets in the nursery phase
}

\section{Acidificantes microencapsulados associados a óleos essenciais e sais de ácidos para leitões em fase de creche}

\author{
Marco Aurelio Callegari ${ }^{1}$; Aliny Ketilim Novais ${ }^{1}$; Eduardo Raele Oliveira ${ }^{1}$; \\ Cleandro Pazinato Dias ${ }^{1}$; Dalita Laurinha Schmoller ${ }^{2}$; Marcino Pereira Junior ${ }^{2}$; \\ Julie Gabriela Nagi Dário ${ }^{3}$; Jefferson Bastos Alves ${ }^{4}$; Caio Abércio da Silva ${ }^{5 *}$
}

\begin{abstract}
The objective of this study was to evaluate the use of commercial blends of organic and inorganic acids combined with essential oils for piglets in the nursery phase. The formulations were administered as microcapsules or as acid salts. Ninety-six, Pen Ar Lan, barrow and female piglets, weaned at a body weight of $600 \mathrm{~kg} \pm 12 \mathrm{~kg}$ and age of 23 days were subjected to four treatments. The animals were distributed in randomized blocks of three animals per pen and 8 replicates per treatment. The treatments consisted of four different diets: control (free of organic acids); acid and essential oil blends (fumaric acid 10,5\%, malic acid 8.0\%, essential oils; in microencapsulated form); microencapsulated acid blend (phosphoric acid 10\%, citric acid 10\%, malic acid 10\%, fumaric acid $20 \%$; in microencapsulated form); and acid salt blend (formic acid $40.5 \%$, phosphoric acid $13.6 \%$, propionic acid $4.9 \%$ and salts $(23.2 \%$ calcium and $4.4 \%$ phosphorus available). The performance parameters, digestive transit time, weights of organs of the digestive tract, bacterial count of feces (Lactobacillus, E coli and Salmonella ssp and Clostridium), $\mathrm{pH}$ of the stomach and duodenal content did not differ between treatment groups $(\mathrm{P}>005)$. All treatments containing organic acids exhibited positive effects on diarrhea control $(\mathrm{P}<005)$. The cecal contents of volatile fatty acids (VFA) were higher in piglets fed diets containing acids than in animals that received the control diet $(\mathrm{P}<005)$, and blends containing essential oils improved the jejunum villus height compared with the control group. The use of diets containing acids improved diarrhea control and VFA production in the cecum, and specifically the diets containing microencapsulated acid blends required the lowest doses to be effective.
\end{abstract}

Key words: Diarrhea. Organic acids. Villi. Volatile fatty acids.

\section{Resumo}

O objetivo deste trabalho foi avaliar o uso de misturas comerciais de ácidos orgânicos e inorgânicos, associados a óleos essenciais, para leitões em fase de creche. Os produtos testados foram administrados na forma microencapsulada ou como sais de ácidos. Foram utilizados 96 leitões da linhagem Pen Ar Lan, machos castrados e fêmeas, desmamados com $6,00 \mathrm{~kg} \pm 1,2 \mathrm{~kg}$ de peso vivo e 23 dias de idade, submetidos a quatro tratamentos. Os animais foram distribuídos em blocos ao acaso, em baias com três animais, contemplando oito repetições por tratamento. Os tratamentos corresponderam às

\footnotetext{
${ }^{1}$ Discentes do Curso de Doutorado do Programa de Pós-Graduação em Ciência Animal, Universidade Estadual de Londrina, UEL, Londrina, PR. Brasil. E-mail: macallegari@vetica.com.br; alinyketilim@hotmail.com; eraele@deheus.com; cleandropazinato@ uol.com.br

${ }^{2}$ Discentes do Curso de Mestrado do Programa de Pós-Graduação em Ciência Animal, UEL, Londrina, PR. Brasil. E-mail: dali_schmoller@hotmail.com; marcinopereira@deheus.com

${ }^{3}$ Discente do Curso de Graduação em Zootecnia, UEL, Londrina, PR. Brasil. E-mail: gabrielanagi@hotmail.com

${ }^{4}$ Discente do Curso de Graduação em Medicina Veterinária, UEL, Londrina, PR. Brasil. E-mail: jefferson.vet62@gmail.com

${ }^{5}$ Prof. Dr., Departamento de Zootecnia, UEL, Londrina, PR. Brasil. E-mail: casilva@uel.br

* Autor para correspondência
} 
seguintes dietas: controle (livre de ácidos orgânicos); mistura de ácidos e óleos essenciais: (ácido fumárico: 10,5\%, ácido málico: 8,0\%, óleos essenciais; na forma microencapsulada); mistura de ácidos microencapsulados (ácido fosfórico: 10\%, ácido cítrico: 10\%, ácido málico: 10\%, ácido fumárico: $20 \%$; na forma microencapsulada); mistura de sais de ácidos (ácido fórmico: 40,5\%, ácido fosfórico: 13,6\%, ácido propiônico: $4,9 \%$ e seus sais: $23,2 \%$ de cálcio e 4,4\% fósforo disponível). Não houve diferença entre os tratamentos para os parâmetros de desempenho, tempo de trânsito da dieta, peso dos órgãos do trato digestório, contagem bacteriana nas fezes (Lactobacillus, E. coli, Salmonella ssp e Clostridiun) e $\mathrm{pH}$ do conteúdo estomacal e duodenal. Todos os tratamentos com ácidos orgânicos determinaram efeito positivo $(\mathrm{P}<0,05)$ no controle da diarreia. Os níveis de ácidos graxos voláteis $(\mathrm{AGV})$ no conteúdo cecal foram mais elevados nos leitões alimentados com dietas contendo ácidos em relação à dieta controle $(\mathrm{P}<0,05)$ e as mistura de ácidos associados com óleos essenciais resultou em maior altura de vilosidades do jejuno em relação ao grupo controle. $\mathrm{O}$ uso de dietas contendo ácidos melhorou o controle da diarreia e a produção de AGV no ceco, sendo observado que a mistura de ácidos orgânicos microencapsulado tem estas ações sob doses mais baixas.

Palavras-chave: Ácidos graxos voláteis. Ácidos orgânicos. Diarréia. Vilosidades.

\section{Introduction}

Weaning is considered a critical time for piglets due to various stressors, especially social (maternal separation and contact with other pigs), environmental (moving to a new location) and nutritional (stopping breastmilk and beginning solid foods) changes One of the most relevant issues for post-weaning piglets is the difficulty in adapting to the new diet (WEARY et al., 2008).

Insufficiencies in digestive enzymes in this phase result in the poor digestion of nutrients (CORASSA et al., 2006), which consequently increases the osmolarity of the contents of the digestive tract and leads to osmotic diarrhea In the post-weaning period, limited feed intake and common changes in the microbiota (UTIYAMA et al., 2006) cause villous atrophy due increases in the rate of epithelial shedding and crypt depth to ensure the replacement of lost cells of the apical region (OETTING et al., 2006). Furthermore, weaning pigs have a limited ability to secrete $\mathrm{HCl}$, which may result in higher gastric $\mathrm{pH}(\mathrm{ROTH}, 2000)$ to increase the risk of diarrhea (LI et al., 2008).

These $\mathrm{pH}$ increases can be attenuated by including organic acids and salts in the diets of weaned piglets Specifically, these components exert bactericidal and bacteriostatic actions (BASSAN et al., 2008; PIVA et al., 2007b). Organic acids are not dissociated passively and diffuse through the cell walls of bacteria, which then dissociate, promoting a reduction in the internal $\mathrm{pH}$ that leads to cell death (SURYANARAYANA et al., 2012). However, the efficiency of acids in the diet may be limited because they are easily absorbed and metabolized after eating, which compromises their action throughout the gastrointestinal tract by reducing their availability (PIVA et al., 2007b).

Thus, the microencapsulation technique has been employed to coat active components (organic acids, essential oils, and others) with a protective layer. The resultant microcapsule slowly and continuously releases the active ingredients throughout the digestive tract, increasing their availability to the lumen of the ileum and colon (MEUNIER et al., 2006).

The objective of this study was to evaluate the effects of supplementation with a commercial mixture of organic acids and inorganic acids mixed with essential oils on the performance, the control of diarrhea and efficiency parameters and the intestinal health of piglets in the nursery phase. The active ingredients were delivered as microcapsules and acid salts.

\section{Materials and Methods}

This experiment was approved by the Institutional Biosafety Committee and the State University of Londrina, CEUA Protocol number 17031201386 
Were used 96 Pen Ar Lan piglets, 64 castrated males and 32 females The piglets were weaned at an average age of 23 days and $600 \pm 12 \mathrm{~kg}$ body weight. The animals were housed in masonry bays that had an area of $297 \mathrm{~m}^{2}$ and featured a compact floor covered with wood shavings, semi-automatic metal feeders, and nipple-type drinkers. The temperature of the pen was controlled via curtains and $250 \mathrm{~W}$ infrared lamps suspended $50 \mathrm{~cm}$ from the floor in the center of the stalls.

The animals were randomly divided into four blocks according to initial weight, with four treatments and eight repetitions. Each repetition represented by a box with three animals (two castrated males and one female)

The treatments consisted of four isonutrient and isocaloric diets: one control diet and three commercial mixtures containing organic and inorganic acids. The diets were formulated to meet the minimum requirements for the high genetic potential of piglets with superior performance. The treatment period included three phases defined as follows (ROSTAGNO et al., 2011): pre initial (2337 days), initial I (38-51 days) and initial II (52 to 63 days) (Tables 1, 2 and 3, respectively).

To formulate the rations, the energy value of the acids and their inclusion levels recommended by the suppliers were considered (Tables 1, 2 and 3). Thus, the following treatments were established: Control: free feed acids and essential oils (control); Blend acids and microencapsulated essential oils: diets containing a commercial product consisting of $105 \%$ fumaric acid, $80 \%$ malic acid and lemon essential oil; Blend of microencapsulated acids: diets containing a commercial product consisting of $10 \%$ phosphoric acid, $10 \%$ citric acid, $10 \%$ malic acid and 20\% fumaric acid; Blend of salts: diets containing a commercial product consisting of $40.5 \%$ of formic acid, $13.6 \%$ phosphoric acid, $4.9 \%$ propionic acid and its salts $(23.2 \%$ calcium and $4.4 \%$ phosphorus available).
The animals received food and water ad libitum throughout the trial period, and their performance was evaluated based on their daily feed intake, daily weight gain and feed conversion.

After an experimental period of 25 days, which corresponded to an average animal age of 48 days, the digestive transit time was assessed using ferric oxide (2\%) as a marker (SCHURCH et al., 1952). For this purpose, 48 animals and 12 repetitions per treatment were evaluated; stalls were selected at random.

Throughout the trial period, the incidence and severity of diarrhea was assessed according to the procedure described by Vassalo et al. (1997) as follows: 0 , feces of normal consistency; 1 , soft stools; 2, soft feces; and 3, watery feces. Scores of 0 and 1 were not considered diarrheic, whereas scores of 2 and 3 were considered diarrheic. All animals that presented level 2 and 3 diarrhea were treated with antibiotics by injection to ensure the continued good health of animals throughout the experiments.

After weighing the animals the end of the experiment (63 days old), one animal whose weight was close to the average weight of the bay was selected from each pen and sacrificed. Each slaughtered animal corresponded to a repeat.

Preceding the sacrifice, the animals were stunned at $350 \mathrm{~V}$ and $13 \mathrm{~A}$ for three seconds using an electric current provided by a Petrovina ${ }^{\circledR}$ IS 2000 instrument with two electrodes. The great vessels (carotid and jugular) of the neck region were cut to bleed the animals. The animals were eviscerated, and the organs of the digestive tract (stomach, small intestine and large intestine) were weighed separately and together

After evisceration, the contents of the stomach and small intestine were removed and packaged separately in plastic containers to determine the $\mathrm{pH}$ using a digital potentiometer ( $\mathrm{pH}$ meter Tec 3MP, Mod MP $03 \mathrm{Tec}$ ) as described by Silveira et al. (2007). 
Table 1. Percentage and calculated energy and composition of the pre-starter diets, according to the treatments.

\begin{tabular}{|c|c|c|c|c|}
\hline \multirow[b]{2}{*}{ Ingredients } & \multicolumn{4}{|c|}{ Experimental diets } \\
\hline & Control & $\begin{array}{l}\text { Acid and essential } \\
\text { oils blend }\end{array}$ & $\begin{array}{l}\text { Microencapsulated } \\
\text { acid blend }\end{array}$ & Acid salt blend \\
\hline Corn ground & 40,00 & 39,93 & 39,80 & 38,70 \\
\hline Soybean meal 46 & 20,00 & 20,00 & 20,00 & 20,00 \\
\hline Degummed soybean oil & 0 & 0 & 0 & 0,45 \\
\hline Control $^{1}$ & 0 & 0 & 0 & 0 \\
\hline Acidifying $^{2}$ & 0 & 0,07 & 0 & 0 \\
\hline Acidifying $^{3}$ & 0 & 0 & 0,20 & 0 \\
\hline Acidifying ${ }^{4}$ & 0 & 0 & 0 & 0,85 \\
\hline $\mathrm{Nc} L 400 \mathrm{P}^{5}$ & 0 & 0 & 0 & 40,00 \\
\hline Nc L $400 \mathrm{TT}^{6}$ & 40,00 & 40,00 & 40,00 & 0 \\
\hline \multicolumn{5}{|l|}{ Nutritional levels } \\
\hline Met. En., Kcal/Kg & 3400 & 3400 & 3400 & 3400 \\
\hline Crude protein $\%$ & 21,000 & 21,000 & 21,000 & 21,000 \\
\hline Crude fat $\%$ & 4,252 & 4,246 & 4,339 & 5,775 \\
\hline Crude fiber $\%$ & 2,349 & 2,350 & 2,347 & 2,664 \\
\hline Ash \% & 5,447 & 5,438 & 5,437 & 7,245 \\
\hline Total calcium \% & 0,710 & 0,710 & 0,710 & 0,710 \\
\hline Total phosphorus \% & 0,575 & 0,575 & 0,575 & 0,575 \\
\hline Lysine Dig \% & 1,350 & 1,350 & 1,350 & 1,350 \\
\hline Met+Cist Dig \% & 0,800 & 0,800 & 0,800 & 0,800 \\
\hline Threonine Dig \% & 0,877 & 0,877 & 0,877 & 0,877 \\
\hline Tryptophan Dig \% & 0,250 & 0,250 & 0,250 & 0,250 \\
\hline Total choline $\mathrm{mg} / \mathrm{kg}$ & 1400 & 1400 & 1400 & 1400 \\
\hline Colistin Total mg/kg & 40,00 & 40,00 & 40,00 & 40,00 \\
\hline Sodium \% & 0,383 & 0,383 & 0,383 & 0,383 \\
\hline
\end{tabular}

${ }^{1}$ Control without organic acids; ${ }^{2}$ Supplied the following per kilogram of product: $10.5 \%$ fumaric acid, $8.0 \%$ malic acid and essential oils of lemon; ${ }^{3}$ Supplied the following per kilogram of product: $10 \%$ phosphoric acid, $10 \%$ citric acid, $10 \%$ malic acid and $20 \%$ fumaric acid; ${ }^{4}$ Supplied the following per kilogram of product: $40.5 \%$ formic acid, $13.6 \%$ phosphoric acid, $4.9 \%$ propionic acid and its salts $(23.2 \%$ calcium and $4.4 \%$ phosphorus available)

${ }^{5}$ Supplied the following per kilogram of product Nucleus $400 \mathrm{P}$ : crude protein (min) $230 \mathrm{~g}$; ether extract (min) $60 \mathrm{~g}$; crude fiber (Max) 20 g; mineral matter (max) 120 g; calcium (Max) 15 g; calcium (min) 7,000 mg; phosphorus (min) 9,000 mg; methionine (min) 9,000 mg; lysine (min) $20 \mathrm{~g}$; threonine (min) 14 g; tryptophan (min) 3,300 mg; vitamin A (min) 12,500 IU; Vitamin D3 (min) 2,500 IU; Vitamin E (min) 40 IU; Vitamin K3 (min) 45 mg; vitamin B1 (min) 2 mg; 75 mg vitamin B2; vitamin B6 25 mg; vitamin B12 (min) $30 \mathrm{mcg}$; Niacin (min) $55 \mathrm{mg}$; Pantothenic acid (min) $225 \mathrm{mg}$; Folic acid (min) $087 \mathrm{mg}$; biotin (min) $0.125 \mathrm{mg}$; choline (min) $250 \mathrm{mg}$; sodium (min) 9,000 mg; Manganese (min) $625 \mathrm{mg}$; zinc (min) 7,000 mg; iron (min) $100 \mathrm{mg}$; copper (min) 375 $\mathrm{mg}$; Iodine ( $\mathrm{min}) 22 \mathrm{mg}$; Selenium $(\mathrm{min}) 0.75 \mathrm{mg}$; phytase $(\mathrm{min}) 1,250$ units; protease (min) 750 units; amylase (min) 750 units; B-glucanase (min) 625 units; Xylanase (min) 1,250 units; Cellulase (min) 1,125 units; colistin 100mg

${ }^{6}$ Supplied the following per kilogram of product Nucleus 400 TT: crude protein (min) $230 \mathrm{~g}$; ether extract (min) $60 \mathrm{~g}$; crude fiber (Max) $20 \mathrm{~g}$; mineral matter $(\max ) 120 \mathrm{~g}$; calcium (Max) $18 \mathrm{~g}$; calcium (min) $10 \mathrm{~g}$; phosphorus (min) 9,000 mg; methionine (min) 9,000 mg; lysine (min) $20 \mathrm{~g}$; threonine ( $\mathrm{min}) 14 \mathrm{~g}$; tryptophan ( $\mathrm{min}) 3,300 \mathrm{mg}$; vitamin A (min) 12,500 IU; vitamin D3 (min) 2,500 IU; vitamin E (min) 40 IU; Vitamin K3 (min) 45 mg; vitamin B1 (min) 2 mg; 75 mg vitamin B2; vitamin B6 25 mg; vitamin B12 (min) $30 \mathrm{mcg}$; Niacin (min) $55 \mathrm{mg}$; Pantothenic acid (min) $225 \mathrm{mg}$; Folic acid (min) $087 \mathrm{mg}$; biotin (min) $0125 \mathrm{mg}$; choline (min) 250 mg; sodium (min) 9,000 mg; Manganese ( $\mathrm{min}) 625$ mg; zinc (min) 7,000 mg; iron (min) 100 mg; copper (min) 375 mg; Iodine (min) $22 \mathrm{mg}$; Selenium (min) $0.75 \mathrm{mg}$; phytase (min) 1,250 units; protease (min) 750 units; amylase (min) 750 units; B-glucanase (min) 625 units; xylanase (min) 1,250 units; cellulase (min) 1,125 units; 100 mg colistin. 
Table 2. Percentage and calculated energy and composition of the initial I diets, according to the treatments.

\begin{tabular}{|c|c|c|c|c|}
\hline \multirow[b]{2}{*}{ Ingredients } & \multicolumn{4}{|c|}{ Experimental diets } \\
\hline & Control & $\begin{array}{l}\text { Acid and essential oils } \\
\text { blend }\end{array}$ & $\begin{array}{l}\text { Microencapsulated } \\
\text { acid blend }\end{array}$ & Acid salt blend \\
\hline Corn ground & 50.00 & 49.94 & 49.80 & 49.25 \\
\hline Soybean meal 46 & 25.00 & 25.00 & 25.00 & 25.00 \\
\hline Degummed soybean oil & 0 & 0 & 0 & 0.25 \\
\hline Control $^{1}$ & 0 & 0 & 0 & 0 \\
\hline Acidifying $^{2}$ & 0 & 0.06 & 0 & 0 \\
\hline Acidifying $^{3}$ & 0 & 0 & 0.20 & 0 \\
\hline Acidifying ${ }^{4}$ & 0 & 0 & 0 & 0.50 \\
\hline $\mathrm{Nc} L 250 \mathrm{P}^{5}$ & 0 & 0 & 0 & 2500 \\
\hline Nc L $250 \mathrm{TT}^{6}$ & 25.00 & 25.00 & 25.00 & 0 \\
\hline \multicolumn{5}{|l|}{ Nutritional levels } \\
\hline Met. En., Kcal/kg & 3375 & 3375 & 3375 & 3375 \\
\hline Crude protein $\%$ & 20.000 & 20.000 & 20.000 & 20.000 \\
\hline Crude fat $\%$ & 4.492 & 4.492 & 4.585 & 4.692 \\
\hline Crude fiber $\%$ & 3.046 & 3.044 & 3.042 & 3.024 \\
\hline Ash \% & 5.937 & 5.936 & 5.934 & 5.579 \\
\hline Total calcium \% & 0.750 & 0.750 & 0.750 & 0.750 \\
\hline Total phosphorus $\%$ & 0.600 & 0.600 & 0.600 & 0.600 \\
\hline Lysine Dig \% & 1.250 & 1.250 & 1.250 & 1.250 \\
\hline Met+Cist Dig \% & 0.750 & 0.750 & 0.750 & 0.750 \\
\hline Threonine Dig \% & 0.810 & 0.810 & 0.810 & 0.810 \\
\hline Tryptophan Dig \% & 0.230 & 0.230 & 0.230 & 0.230 \\
\hline Total Cholina $\mathrm{mg} / \mathrm{kg}$ & 1310 & 1310 & 1310 & 1310 \\
\hline Colistin Total $\mathrm{mg} / \mathrm{kg}$ & 40.00 & 40.00 & 40.00 & 40.00 \\
\hline Sodium \% & 0.35 & 0.35 & 0.35 & 0.35 \\
\hline
\end{tabular}

${ }^{1}$ Control without organic acids; ${ }^{2}$ Supplied the following per kilogram of product: acid, $10 \%$ citric acid, $10 \%$ malic acid and $20 \%$ fumaric acid; ${ }^{4}$ Supplied the following per kilogram of product: $40.5 \%$ formic acid, $13.6 \%$ phosphoric acid, $4.9 \%$ propionic acid and its salts $(23.2 \%$ calcium and $4.4 \%$ phosphorus available)

${ }^{5}$ Supplied the following per kilogram of product P Nucleus 250: crude protein $(\mathrm{min}) 210 \mathrm{~g}$; ether extract (min) $80 \mathrm{~g}$; crude fiber (Max) $30 \mathrm{~g}$; mineral matter (max) 160 gr; calcium $(\max ) 25 \mathrm{~g}$; calcium (min) $20 \mathrm{~g}$; phosphorus (min) $11 \mathrm{~g}$; methionine (min) 10 g; lysine (min) $20 \mathrm{~g}$; threonine (min) $14 \mathrm{~g}$; tryptophan (min) 3,000 mg; vitamin A (min) 20,000 IU; vitamin D3 (min) 4,000 IU; vitamin E (min) 64 IU; Vitamin K3 (min) 72 mg; vitamin B1 (min) 32 mg; Vitamin B2 (min) 12 mg; vitamin B6 (min) 4 mg; vitamin B12 (min) 48 mcg; Niacin (min) $88 \mathrm{mg}$; Pantothenic acid (min) $36 \mathrm{mg}$; Folic acid (min) $14 \mathrm{mg}$; biotona (min) $02 \mathrm{mg}$; sodium (min) $10 \mathrm{~g}$; Manganese (min) $100 \mathrm{mg}$; zinc (min) 9,200 mg; iron (min) $160 \mathrm{mg}$; copper (min) $800 \mathrm{mg}$; Iodine (min) $37 \mathrm{mg}$; Selenium ( $\mathrm{min}$ ) $12 \mathrm{mg}$; phytase ( $\mathrm{min})$ 2,000 units; protease (min) 1,200 units; amylase (min) 1,200 units; B-glutanase (min) 1,000 units; xylanase $(\min ) 2,000$ units; cellulase $(\min ) 1,800$ units; $160 \mathrm{mg}$ colistin

${ }^{6}$ Supplied the following per kilogram of product Core 250 TT: Crude protein (min) $210 \mathrm{~g}$; ether extract (min) $80 \mathrm{~g}$; crude fiber (Max) 30 g; mineral matter (max) 160 gr; calcium (max) 30 g; calcium (min) 20 g; phosphorus (min) 12 g; methionine (min) 10 g; lysine (min) $20 \mathrm{~g}$; Threonine (min) $14 \mathrm{~g}$; tryptophan (min) 3,000 mg; vitamin A (min) 20,000 IU; vitamin D3 (min) 4,000 IU; vitamin E (min) 64 IU; Vitamin K3 (min) 72 mg;vitamina B1 (min) 32 mg; Vitamin B2 (min) 12 mg; vitamin B6 (min) 4 mg; vitamin B12 (min) 48 mcg; Niacin (min) 88 mg; Pantothenic acid (min) 36 mg; Folic acid (min) 14 mg; biotin (min) $02 \mathrm{mg}$; sodium (min) 10 g; Manganese (min) $100 \mathrm{mg}$; zinc (min) 9,200 mg; iron (min) 160 mg; copper (min) $800 \mathrm{mg}$; Iodine (min) $37 \mathrm{mg}$; Selenium (min) $12 \mathrm{mg}$; phytase ( $\mathrm{min}$ ) 2,000 units; protease (min) 1,200 units; amylase (min) 1,200 units; B-glutanase (min) 1,000 units; xylanase (min) 2,000 units; cellulase (min) 1,800 units; $160 \mathrm{mg}$ colistin 
Table 3. Percentage and calculated energy and composition of the initial II diets, according to the treatments.

\begin{tabular}{|c|c|c|c|c|}
\hline \multirow[b]{2}{*}{ Ingredients } & \multicolumn{4}{|c|}{ Experimental diets } \\
\hline & Control & $\begin{array}{l}\text { Acid and essential oils } \\
\text { blend }\end{array}$ & $\begin{array}{l}\text { Microencapsulated acid } \\
\text { blend }\end{array}$ & $\begin{array}{c}\text { Acid salt } \\
\text { blend }\end{array}$ \\
\hline Corn ground & 64.40 & 64.32 & 64.20 & 63.64 \\
\hline Soybean meal 46 & 30.50 & 30.50 & 30.50 & 30.50 \\
\hline Degummed soybean oil & 0.10 & 0.12 & 0.10 & 0.36 \\
\hline Control $^{1}$ & 0 & 0 & 0 & 0 \\
\hline Acidifying ${ }^{2}$ & 0 & 0.06 & 0 & 0 \\
\hline Acidifying $^{3}$ & 0 & 0 & 0.20 & 0 \\
\hline Acidifying $^{4}$ & 0 & 0 & 0 & 0.50 \\
\hline Nc L 50 TTA $^{5}$ & 0 & 0 & 0 & 5.00 \\
\hline Nc L $50 \mathrm{TT}^{6}$ & 5.00 & 5.00 & 5.00 & 0 \\
\hline \multicolumn{5}{|l|}{ Nutritional levels } \\
\hline Met. En., Kcal/kg & 3250 & 3250 & 3250 & 3250 \\
\hline Crude protein $\%$ & 19.000 & 19.000 & 19.000 & 19.000 \\
\hline Crude fat $\%$ & 2.970 & 2.990 & 3.063 & 3.201 \\
\hline Crude fiber \% & 3.259 & 3.258 & 3.255 & 3.244 \\
\hline Ash \% & 7.042 & 7.041 & 7.039 & 7.043 \\
\hline Total calcium \% & 0.779 & 0.779 & 0.779 & 0.779 \\
\hline Total phosphorus \% & 0.537 & 0.537 & 0.537 & 0.537 \\
\hline Lysine Dig \% & 1.050 & 1.050 & 1.050 & 1.050 \\
\hline Met+Cist Dig \% & 0.615 & 0.615 & 0.615 & 0.615 \\
\hline Threonine Dig \% & 0.632 & 0.632 & 0.632 & 0.632 \\
\hline TryptophanDig \% & 0.204 & 0.204 & 0.204 & 0.204 \\
\hline Coline Total mg/kg & 1240 & 1240 & 1240 & 1240 \\
\hline Halquinol mg/kg & 120.00 & 120.00 & 120.00 & 120.00 \\
\hline Sodium $\%$ & 0.222 & 0.222 & 0.222 & 0.222 \\
\hline
\end{tabular}

${ }^{1}$ Control without organic acids; ${ }^{2}$ Supplied the following per kilogram of product: $10.5 \%$ fumaric acid, $8.0 \%$ malic acid and essential oils of lemon; ${ }^{3}$ Supplied the following per kilogram of product: $10 \%$ phosphoric acid, $10 \%$ citric acid, $10 \%$ malic acid and $20 \%$ fumaric acid; ${ }^{4}$ Supplied the following per kilogram of product: $40.5 \%$ formic acid, $13.6 \%$ phosphoric acid, $4.9 \%$ propionic acid and its salts $(23.2 \%$ calcium and $4.4 \%$ phosphorus available)

${ }^{5}$ Supplied the following per kilogram of product Core 50 TTA: calcium (Max) $120 \mathrm{~g}$; calcium (min) $80 \mathrm{~g}$; phosphorus (min) $39 \mathrm{~g}$; lysine (min) 24 g; methionine (min) 14 g; threonine (min) 9,000 mg; vitamin A (min) 100000 IU; vitamin D3 (min) 20,000 IU; vitamin E (min) 320 IU; Vitamin K3 (min) 36 mg; vitamin B1 (min) 16 mg; Vitamin B2 (min) 60 mg; vitamin B6 (min) 20 mg; Vitamin B12 240 mcg; Niacin (min) 440 mg; pantothenic acid (min) 180, MG; Folic acid (min) 7 mg; biotin (min) 1 mg; hill (min) 2,114 mg; sodium (min) 40 g; Manganese (min) 500 mg; zinc (min) 1,100 mg; iron (min) 800 mg; copper (min) 3,000 mg; Iodine (min) 1850 mg; Selenium ( $\mathrm{min}) 6 \mathrm{mg}$; BHT ( $\mathrm{min}) 1,500 \mathrm{mg}$; phytase (min) 10,000 units; protease (min) 6,000 units; amylase (min) 6,000 units; B-glucanase ( $\mathrm{min}$ ) 5,000 units; xylanase ( $\mathrm{min}$ ) 10,000 units; cellulase (min) 9,000 units; halquinol 2,400 mg

${ }^{6}$ Supplied the following per kilogram of product Core 50 TT: calcium (Max) 140 g; calcium (min) 100 g; phosphorus (min) 40 g; lysine (min) 24 g; methionine (min) 14 g; threonine (min) 9,000 mg; vitamin A (min) 100000 IU; vitamin D3 (min) 20,000 IU; vitamin E (min) 320 IU; Vitamin K3 (min) 36 mg; vitamin B1 (min) 16 mg; Vitamin B2 (min) 60 mg; vitamin B6 (min) 20 mg; Vitamin B12 240 mcg; Niacin (min) 440 mg; Pantothenic acid (min) $180 \mathrm{mg}$; Folic acid (min) $7 \mathrm{mg}$; biotin (min) $1 \mathrm{mg}$; hill (min) 2,114 mg; sodium (min) 40 g; Manganese (min) 500 mg; zinc (min) 1,100 mg; iron (min) 800 mg; copper (min) 3,000 mg; Iodine (min) $1850 \mathrm{mg}$; Selenium (min) 6 mg; BHT (min) 1,500 mg; phytase (min) 10,000 units; protease (min) 6,000 units; amylase (min) 6,000 units; B-glucanase (min) 5,000 units; xylanase (min) 10,000 units; cellulase (min) 9,000 units; halquinol 2,400 mg

Immediately after evisceration, gut fragments were collected (approximately $3 \mathrm{~cm}$ ) relative to the sized portions of the duodenum, jejunum and ileum. The tissues were washed with $09 \%$ saline before being fixed in 10\% formalin, dehydrated in alcohol, diaphanized in xylene, and embedded in paraffin Longitudinal and semi-serial sections were then cut from the tissues and stained with hematoxylin-eosin. The morphometry of the sections was evaluated on an Olympus model BX41 microscope coupled 
to an Olympus DP11-N system to capture images. The images were transferred to a computer, and morphometric evaluations were performed using the Image-Pro Plus ${ }^{\circledR}$ software program, which measured the villus height and crypt depth, in a total of 10 randomly selected intestinal sections at $40 \mathrm{x}$ magnification.

The fecal content (120 g on average) was directly collected from the large intestine, identified and stored in a cooler with ice. After all sacrifices were complete, the samples were sent to the laboratory under refrigeration and submitted to a Clostridium sulfite reducer count according to Instruction No 62 (BRASIL, 2003) to count the number of E coli and Lactobacillus ssp cells. All procedures were carried out in accordance with the procedures specified in the Analysis Methods Guide Microbiological Food and Water (SILVA et al., 2010), and Salmonella $s s p$ were isolated according to Ordinance No 126 (BRASIL, 1995).
The short chain fatty acids were identified (ERWIN et al., 1961) using a gas chromatograph (Focus GC; Thermo Scientific) equipped with a glass column three meters in length and $1 / 4$ " inches in diameter; the column was packed with $80 / 120$ Carbopack B-DA / 4\% Carbowax 20M.

The data were submitted to a variance analysis; the parametric data were compared using Tukey's test, and the non-parametric data were compared using a chi squared test according to the distribution of normality using the MINITAB 16 system.

\section{Results and Discussion}

None of the analyzed parameters differed between treatment groups (Table 4) $(\mathrm{P}>005)$ in any of the phases throughout the test period.

Table 4. Means of daily weight gain (DWG), daily feed intake (DFI), feed conversion ratio (FC) and final weight (FW), according to the phases, of piglets submitted to different treatments.

\begin{tabular}{|c|c|c|c|c|c|c|c|}
\hline \multirow[b]{2}{*}{ Treatments } & \multirow[b]{2}{*}{ Control $^{1}$} & \multicolumn{2}{|c|}{ Microencapsulated } & \multirow[b]{2}{*}{$\begin{array}{c}\text { Acid salt } \\
\text { blend }^{4}\end{array}$} & \multirow[b]{2}{*}{$\begin{array}{l}\text { General } \\
\text { average }\end{array}$} & \multirow[b]{2}{*}{$P$ value } & \multirow[b]{2}{*}{$\mathrm{VC} \%$} \\
\hline & & $\begin{array}{l}\text { Acid and essential } \\
\text { oils blend }^{2}\end{array}$ & Acid blend ${ }^{3}$ & & & & \\
\hline \multicolumn{8}{|c|}{ Phases } \\
\hline \multicolumn{8}{|c|}{ Pre start (23 to 37 days) } \\
\hline DWG $(\mathrm{kg})$ & 0.303 & 0.295 & 0.292 & 0.282 & 0.293 & 0.715 & 12.82 \\
\hline DFI $(\mathrm{kg})$ & 0.500 & 0.514 & 0.521 & 0.514 & 0.513 & 0.767 & 12.92 \\
\hline $\mathrm{FC}$ & 1.702 & 1.773 & 1.823 & 1.869 & 1.790 & 0.773 & 18.24 \\
\hline \multicolumn{8}{|c|}{ Initial I (37 to 51 days) } \\
\hline DWG (kg) & 0.538 & 0.567 & 0.537 & 0.555 & 0.547 & 0.759 & 11.02 \\
\hline DFI (kg) & 0.804 & 0.796 & 0.801 & 0.801 & 0.801 & 0.997 & 9.24 \\
\hline $\mathrm{FC}$ & 1.494 & 1.404 & 1.492 & 1.443 & 1.464 & 0.741 & 7.83 \\
\hline \multicolumn{8}{|c|}{ Initial II (51 to 63 days) } \\
\hline DWG (kg) & 0.703 & 0.728 & 0.687 & 0.756 & 0.716 & 0.754 & 15.16 \\
\hline DFI $(\mathrm{kg})$ & 1.229 & 1.282 & 1.251 & 1.287 & 1.259 & 0.978 & 9.24 \\
\hline $\mathrm{FC}$ & 1.748 & 1.639 & 1.821 & 1.702 & 1.758 & 0.656 & 11.82 \\
\hline \multicolumn{8}{|c|}{ Total period (23 to 63 days) } \\
\hline DWG (kg) & 0.496 & 0.511 & 0.488 & 0.508 & 0.499 & 0.898 & 11.99 \\
\hline DFI (kg) & 0.804 & 0.820 & 0.816 & 0.823 & 0.815 & 0.989 & 9.52 \\
\hline $\mathrm{FC}$ & 1.635 & 1.607 & 1.642 & 1.646 & 1.635 & 0.881 & 6.53 \\
\hline FW $(\mathrm{kg})$ & 26.13 & 26.71 & 25.74 & 26.69 & 26.26 & 0.66 & 13.2 \\
\hline
\end{tabular}

${ }^{1}$ Control without organic acids; ${ }^{2}$ Supplied the following per kilogram of product: $10.5 \%$ fumaric acid. $8.0 \%$ malic acid and essential oils of lemon; ${ }^{3}$ Supplied the following per kilogram of product: $10 \%$ phosphoric acid. 10\% citric acid. $10 \%$ malic acid and $20 \%$ fumaric acid; ${ }^{4}$ Supplied the following per kilogram of product: $40.5 \%$ formic acid, $13.6 \%$ phosphoric acid, $4.9 \%$ propionic acid and its salts $(23.2 \%$ calcium and $4.4 \%$ phosphorus available). 
The performance parameters of animals in all treatments remained within the ranges proposed for this strain. Therefore, the conditions were hypothesized to favor animal development, independent of the treatment employed. As such, the results may have been influenced by the environment, which differed from that of a commercial farm. Specifically, the health of animals in this facility was less challenged than it would have been in a commercial facility because the test facility was infrequently used and continuously monitored. For example, the stalls were cleaned daily, and the food was abundant. Furthermore, each pen contained few animals, which reduces disputes over food, improves consumption and consequently improves performance. Moreover, the diets contained lactose $(6 \%$ in the pre-initial phase and $3 \%$ in the initial phase I) and zinc oxide $(3,680$ ppm in the pre-starter feed and 3,000 ppm in the initial feed I). As reported by Silva et al. (2008), the fermentation of dietary lactose into lactic acid in the digestive tract reduces the need for diet acidification Zinc oxide also plays an important role in intestinal health by minimizing enteric problems.
Thus, the differences between the findings of our study and those of previous studies examining the use of dietary acids for piglets in the nursery phase are likely due to variations in the experimental conditions, such as the nutritional quality of diets, acid profile, supplementation level and concentration of acidifying supplements, environmental challenge and health of the animals (BLANK et al., 1999; MROZ, 2005; PASTUSZEWSKA et al., 2007).

Based on the diarrhea score (Table 5), diarrhea was most severe in piglets fed a diet lacking organic acids (control) $(\mathrm{P}<0,05)$ compared with other treatments. These effects are attributed primarily to two conditions, decreased gastric $\mathrm{pH}$, which directly reduces the presence of pathogens in the stomach (PARTANEN; MROZ, 1999), and the bactericidal and bacteriostatic actions of acids. Specifically, these acids are lipophilic and readily cross the cell membranes of bacteria, particularly gram-negative bacteria This process results in cell death because most of the cell's energy is diverted toward expelling protons through the membrane (SURYANARAYANA et al., 2012).

Table 5. Percentage of diarrhea of weaned piglets during the pre-initial phase ( 0 to 14 days) according the treatments.

\begin{tabular}{ccccccc}
\hline & & \multicolumn{2}{c}{ Microencapsulated } & & & \\
\cline { 3 - 4 } Treatments & Control $^{1}$ & $\begin{array}{c}\text { Acid and essential } \\
\text { oils blend }\end{array}$ & Acid blend $^{3}$ & $\begin{array}{c}\text { Acid salt } \\
\text { blend }^{4}\end{array}$ & General average & P value \\
\hline $\begin{array}{c}\text { Animais com } \\
\text { diarreia }\end{array}$ & $62.5^{\mathrm{b}}$ & $20.83^{\mathrm{a}}$ & $33.33^{\mathrm{a}}$ & $25.0^{\mathrm{a}}$ & 35.0 & 0.012 \\
\hline
\end{tabular}

${ }^{1}$ Control without organic acids; ${ }^{2}$ Supplied the following per kilogram of product: $10.5 \%$ fumaric acid. $8.0 \%$ malic acid and essential oils of lemon; ${ }^{3}$ Supplied the following per kilogram of product: $10 \%$ phosphoric acid. $10 \%$ citric acid. $10 \%$ malic acid and $20 \%$ fumaric acid; ${ }^{4}$ Supplied the following per kilogram of product: $40.5 \%$ formic acid, $13.6 \%$ phosphoric acid, $4.9 \%$ propionic acid and its salts $(23.2 \%$ calcium and $4.4 \%$ phosphorus available).

Different letters in the same column are significantly different by chi square test $(\mathrm{p} \leq 0.05)$.

The high frequency of diarrhea at this stage is due to the immaturity of the digestive and immune systems of piglets. Diarrhea may also be caused by the presence of undigested and unabsorbed food residues that serve as a substrate for pathogens (BRAZ, 2008).
The frequency of diarrhea was lower in piglets that received mixed acids than in the control group, which corroborates observations made by Freitas et al. (2006). However, contrary to the results obtained herein, Corassa et al. (2012), who examined the effects of citric and sorbic acid, and Miguel et al. (2011), who examined diets containing different 
organic acids (potassium diformiato, fumaric acid, citric acid, or benzoic acid), found that supplementation with these acids in the diet did not improve symptoms of diarrhea compared with the control.

The blend of coated organic acids and the blend of acid salts, which were used at higher concentrations, had the same effect on diarrhea control, confirming that microencapsulation lowers the concentration of acids required for diarrhea control (PIVA et al., 2007a). Similarly, the required dose of the blend of organic acids and essential oils to control diarrhea was also lower than the required dose of acid salts, demonstrating the synergistic effect of essential oils and organic acids (PIVA et al., 2007b).

The average $\mathrm{pH}$ values of the stomach contents and the small intestine (Table 6) did not differ (P> 005) between treatments. These results may be due to the fact that the quantity of ingested acids (SILVA et al., 2008) was not high enough to reduce the $\mathrm{pH}$. Furthermore, the dietary buffer provided by the minerals and proteins can also hinder lowering of the $\mathrm{pH}$. Notably, the acid blends were also microencapsulated, and these capsules dissociated in the stomach and passed through the small gut intact; however, this hypothesis for the $\mathrm{pH}$ change in this organ was not confirmed.

Table 6. $\mathrm{pH}$ of the stomach and small intestine contents of pigs according the treatments.

\begin{tabular}{cccccccc}
\hline & & \multicolumn{2}{c}{ Microencapsulated } & & & \\
\cline { 3 - 5 } Treatments & Control $^{1}$ & $\begin{array}{c}\text { Acid and essential } \\
\text { oils blend }^{2}\end{array}$ & $\begin{array}{c}\text { Acid } \\
\text { blend }^{3}\end{array}$ & $\begin{array}{c}\text { Acid salt } \\
\text { blend }\end{array}$ & $\begin{array}{c}\text { General } \\
\text { average }\end{array}$ & P value & VC\% \\
\hline Stomach & 4.39 & 3.81 & 4.98 & 3.80 & 4.16 & 0.24 & 23.77 \\
Small gut & 6.20 & 5.97 & 6.24 & 6.25 & 6.17 & 0.36 & 5.73 \\
\hline
\end{tabular}

${ }^{1}$ Control without organic acids; ${ }^{2}$ Supplied the following per kilogram of product: $10.5 \%$ fumaric acid. $8.0 \%$ malic acid and essential oils of lemon; ${ }^{3}$ Supplied the following per kilogram of product: 10\% phosphoric acid. 10\% citric acid. 10\% malic acid and $20 \%$ fumaric acid; ${ }^{4}$ Supplied the following per kilogram of product: $40.5 \%$ formic acid, $13.6 \%$ phosphoric acid, $4.9 \%$ propionic acid and its salts (23.2\% calcium and $4.4 \%$ phosphorus available).

One factor limiting the effectiveness of the acid is its rapid absorption when it leaves the stomach Piva et al. (2007b) studied weaned piglets and found that adding a blend of microencapsulated organic acids and plant extracts to the food did not significantly affect the $\mathrm{pH}$ of the stomach. Differences were only detected in the flow of the jejunum, and the highest $\mathrm{pH}$ was observed in response to the control diet.

Freitas et al. (2006) studied a blend of organic acids (levels of 0, 0.78, 0.84 and $0.90 \%$ ) in the diet of piglets between 21 and 35 days of age and found that these treatments did not reduce the stomach $\mathrm{pH}$ of animals. These findings corroborated those of Braz et al. (2011), who studied a blend of propionic acid, acetic acid, formic acid, citric acid and calcium, and Gomes et al. (2011), who studied diets containing fumaric acid or combination with lactic acid or calcium propionate or combination of the three acids, for weaned piglets. They only found $\mathrm{pH}$ reductions in the colon, and the $\mathrm{pH}$ in the stomach and jejunum did not change.

Many studies have shown that modifying the $\mathrm{pH}$ of the stomach and intestine in a pig is almost impossible, even when administering large quantities of organic acids in the diet (CORASSA et al., 2012). Costa et al. (2013) reported that comparing the gastric $\mathrm{pH}$ of animals receiving organic acids is difficult. The authors attribute this difficulty to the wide variations in the methods used to measure the $\mathrm{pH}$ of the stomach. Alternatively, the stomach contents may be contaminated with spittle or duodenal contents at slaughter, which may 
increase the gastric $\mathrm{pH}$ due to alkaline substances in the stomach (BRAZ et al., 2011).

The digestive transit time did not differ between treatments (Table 7). Reductions in the gastric
$\mathrm{pH}$ shorten the transit time and increase gastric retention due to increases in the proteolytic activity of enzymes (COSTA et al., 2013). This lack of change in the transit time can be attributed to the lack of acidification of the stomach.

Table 7. Transit time of digesta of weaned piglets according the treatments.

\begin{tabular}{rccccc}
\hline & & \multicolumn{2}{c}{ MIcorencapsulated } & & \\
\cline { 3 - 5 } Treatments & Control $^{1}$ & Acid and essential oils blend $^{2}$ & Acid blend $^{3}$ & Acid salt blend $^{4}$ & P Value \\
\hline $\begin{array}{r}\text { Time in } \\
\text { minutes }\end{array}$ & 573.5 & 560.5 & 547.6 & 572.4 & 0.57 \\
\hline
\end{tabular}

${ }^{1}$ Control without organic acids; ${ }^{2}$ Supplied the following per kilogram of product: $10.5 \%$ fumaric acid. $8.0 \%$ malic acid and essential oils of lemon; ${ }^{3}$ Supplied the following per kilogram of product: 10\% phosphoric acid. 10\% citric acid. 10\% malic acid and $20 \%$ fumaric acid; ${ }^{4}$ Supplied the following per kilogram of product: $40.5 \%$ formic acid, $13.6 \%$ phosphoric acid, $4.9 \%$ propionic acid and its salts (23.2\% calcium and $4.4 \%$ phosphorus available).

Regarding the AGV in the cecum (Table 8), the treatments significantly affected $(\mathrm{P}<005)$ the production of acetic acid and propionic acid. Specifically, the control diet resulted in lower AGV concentrations compared with those of the other treatment. The levels of butyric acid were higher ( $\mathrm{P}$ $<005$ ) in the blend of essential oils and fatty acids and in the blend of microencapsulated acids than in the control, which did not differ from the blend of acid salts. The diets did not affect the production of valeric acid $(\mathrm{P}>005)$. These results are attributed to changes in the microbial populations of the small and large intestines, favoring the survival of lactic acidproducing bacteria and the reducing the population of pathogenic bacteria (MICHIELS et al., 2009), which changed the VFA pattern (VAN BEERSSCHREURS et al., 1998; SURYANARAYANA et al., 2012). These effects were most pronounced when the essential oils and organic acids were microencapsulated, which improved the ability of these acids to reach the large intestine and remain active (MEUNIER et al., 2006).

Table 8. Concentration of volatile fatty acids $(\mathrm{mmol} / \mathrm{L})$ in the cecal contents of weaned piglets according the treatments.

\begin{tabular}{lcccccc}
\hline & & \multicolumn{2}{c}{ Microencapsulated } & & \\
\cline { 3 - 4 } Treatments & Control $^{1}$ & $\begin{array}{c}\text { Acid and essential oils } \\
\text { blend }^{2}\end{array}$ & Acid blend $^{3}$ & Acid salt blend & P Value & VC\% \\
\hline Acetic acid & $8.03^{\mathrm{b}}$ & $17.17^{\mathrm{a}}$ & $19.35^{\mathrm{a}}$ & $17.43^{\mathrm{a}}$ & 0.00 & 34.71 \\
Propionic acid & $7.09^{\mathrm{b}}$ & $12.88^{\mathrm{a}}$ & $14.09^{\mathrm{a}}$ & $11.46^{\mathrm{a}}$ & 0.001 & 36.14 \\
Butyric acid & $3.18^{\mathrm{b}}$ & $6.06^{\mathrm{a}}$ & $5.86^{\mathrm{a}}$ & $5.10^{\mathrm{ab}}$ & 0.018 & 41.94 \\
Valeric acid & 0.87 & 1.42 & 1.34 & 1.32 & 0.654 & 75.24 \\
\hline
\end{tabular}

${ }^{1}$ Control without organic acids; ${ }^{2}$ Supplied the following per kilogram of product: $10.5 \%$ fumaric acid. $8.0 \%$ malic acid and essential oils of lemon; ${ }^{3}$ Supplied the following per kilogram of product: 10\% phosphoric acid. 10\% citric acid. 10\% malic acid and $20 \%$ fumaric acid; ${ }^{4}$ Supplied the following per kilogram of product: $40.5 \%$ formic acid, $13.6 \%$ phosphoric acid, $4.9 \%$ propionic acid and its salts $(23.2 \%$ calcium and $4.4 \%$ phosphorus available).

Different letters in the same column are significantly different by Tukey test $(\mathrm{p} \leq 0.05)$. 
The changes in the AGV levels observed in this study also corroborate those observed by Grilli et al. (2010) and Willamil et al. (2011), who revealed that microencapsulated organic acids can modify and improve cecal fermentation.

Notably, the blend of microencapsulated essential oils and acids and the blend of microencapsulated acids efficiently promoted the production of VFAs, even at low doses and acid concentrations. This finding demonstrates that microencapsulation prevents the absorption and immediate metabolism of duodenal acids (PIVA et al., 2007b) to ensure that sufficient quantities are available at the end of the digestive tract (MEUNIER et al., 2006).

Morphometric differences ( $\mathrm{P}<005)$ were only observed in the villus height of the jejunum (Table 9). Specifically, the morphometric parameters of animals that received the blend of essential oils and acids were improved compared with the parameters of those in the control group. Organic acids are recognized to prevent the colonization and proliferation of pathogenic bacteria in the gut to exert positive actions, such as maintaining organ integrity and promoting mucosal villus height (OWUSU-ASIEDU et al., 2003). Moreover, essential oils can stimulate digestive secretions (PLATEL; SRINIVASAN, 2004), which favors intestinal morphological development (UTIYAMA et al., 2006).

Crypt depth differences $(\mathrm{P}<005)$ were observed in the duodenum, where the treatment blend of microencapsulated acids increased the crypt depth compared with the other treatments. The ratio of villus height/crypt depth only differed in the jejunum. Specifically, the treatment blend of essential oils and acids improved this ratio compared with the control treatment and the blend of microencapsulated acids. Again, this finding indicates the positive and synergistic effect of acids and essential oils on the intestinal mucosa (OWUSU-ASIEDU et al., 2003; PLATEL; SRINIVASAN, 2004; UTIYAMA et al., 2006).

Table 9. Means (expressed in $\mathrm{nm}$ ) of duodenum villus height, crypt depth and villus height / crypt depth ratio of weaned piglets according the treatments.

\begin{tabular}{lcccccc}
\hline \multicolumn{7}{c}{ Microencapsulated } \\
\hline Treatments & Control $^{1}$ & $\begin{array}{c}\text { Acid and essential } \\
\text { oils blend }\end{array}$ & Acid blend $^{3}$ & $\begin{array}{c}\text { Acid salt } \\
\text { blend }^{4}\end{array}$ & P Value & VC\% \\
\hline $\begin{array}{l}\text { Villus height } \\
\text { Duodenum }\end{array}$ & 269.9 & 297.6 & 284.9 & 293.8 & 0.769 & 19.25 \\
Jejunum & $193.0^{\mathrm{b}}$ & $277.0^{\mathrm{a}}$ & $223.0^{\mathrm{ab}}$ & $257.0^{\mathrm{ab}}$ & 0.023 & 25.91 \\
Ileum & 239.3 & 241.9 & 237.5 & 224.7 & 0.914 & 20.07 \\
\hline Crypt depth & & & & & \\
Duodenum & $442.0^{\mathrm{b}}$ & $433.0^{\mathrm{b}}$ & $558.0^{\mathrm{a}}$ & $439.0^{\mathrm{b}}$ & 0.000 & 16.59 \\
Jejunum & 387.6 & 320.4 & 387.5 & 358.0 & 0.368 & 109.42 \\
Íleum & 339.0 & 322.0 & 422.0 & 317.0 & 0.320 & 106.34 \\
\hline Villus / crypt & & & & & \\
Duodenum & 0.611 & 0.688 & 0.510 & 0.670 & 0.037 & 23.97 \\
Jejunum & $0.497^{\mathrm{b}}$ & $0.866^{\mathrm{a}}$ & $0.575^{\mathrm{b}}$ & $0.718^{\mathrm{ab}}$ & 0.040 & 33.06 \\
Ileum & 0.705 & 0.752 & 0.564 & 0.710 & 0.419 & 27.27 \\
\hline
\end{tabular}

${ }^{1}$ Control without organic acids; ${ }^{2}$ Supplied the following per kilogram of product: $10.5 \%$ fumaric acid. $8.0 \%$ malic acid and essential oils of lemon; ${ }^{3}$ Supplied the following per kilogram of product: $10 \%$ phosphoric acid. $10 \%$ citric acid. $10 \%$ malic acid and $20 \%$ fumaric acid; ${ }^{4}$ Supplied the following per kilogram of product: $40.5 \%$ formic acid, $13.6 \%$ phosphoric acid, $4.9 \%$ propionic acid and its salts $(23.2 \%$ calcium and $4.4 \%$ phosphorus available).

Different letters in the same column are significantly different by Tukey test $(\mathrm{p} \leq 0.05)$. 
Despite the discrepancies, the overall results indicate that diets containing acids are preferable to the control diet, especially with respect to the villus height and villus/crypt ratio of the jejunum, an important absorptive region and producer of enzymes. Specifically, Braz et al. (2011) found that a blend of organic acids optimized the intestinal morphology. Conversely, Gomes et al. (2007) found that the combination of $1 \%$ fumaric acid, $01 \%$ butyric acid and $05 \%$ formic acid in the diet of piglets at three weeks post-weaning reduced the villus height in the duodenum

The numbers of Lactobacillus spp and Escherichia coli (Table 10) did not differ between treatments $(\mathrm{P}>005)$, and the lack of Salmonella and Clostridium ssp were also observed. Organic acids and essential oils are known to aid the control of pathogenic microorganisms and favor the development of beneficial bacteria (OWUSUASIEDU et al., 2003; PLATEL; SRINIVASAN, 2004; UTIYAMA et al., 2006). However, the positive impacts of the experimental environment and management on the health of animals may have been a confounding factor in the effects of dietary supplementation on bacterial content.

Our findings agree with those reported by Kasprowicz-Potocka et al. (2009), who noted that fumaric acid did not affect the Clostridium perfringens count of Lactobacillus and E coli. However, the addition of benzoic acid increased the Clostridium perfringens populations in the feces collected from the cecum and duodenum.

Our results also corroborate those of Gebru et al. (2010). Specifically, we observed that including a blend of microencapsulated organic and inorganic acids in the diet had an effect on Salmonella that was similar to that of chlortetracycline in the control 6 and 14 days after contamination. Moreover, Freitas et al. (2006) observed that a blend of lactic, acetic and phosphoric acids at proportions of $0.84 \%$ and $0.63 \%$ from 21 to 35 and 36 to 49 days of age, respectively, efficiently controlled the bacterial populations, as evidenced by a lack of $E$ coli and Streptococcus spp.

Table 10. Lactobacillus spp, E. coli, Salmonella spp. and Clostridium perfringens count in the feces of weaned piglets according the treatments.

\begin{tabular}{|c|c|c|c|c|c|c|}
\hline \multirow[b]{2}{*}{ Treatments } & \multirow[b]{2}{*}{ Control $^{1}$} & \multicolumn{2}{|c|}{ Microencapsulated } & \multirow[b]{2}{*}{$\begin{array}{l}\text { Acid salt } \\
\text { blend }^{4}\end{array}$} & \multirow[b]{2}{*}{ P Value } & \multirow[b]{2}{*}{$\mathrm{VC} \%$} \\
\hline & & $\begin{array}{l}\text { Acid and essential } \\
\text { oils blend }{ }^{2}\end{array}$ & Acid blend ${ }^{3}$ & & & \\
\hline Lactobacillus SSP & $1.9 \times 10^{8}$ & $1.3 \times 10^{8}$ & $1.2 \times 10^{8}$ & $1.6 \times 10^{8}$ & 0.71 & 72.87 \\
\hline E coli & $3.4 \times 10^{6}$ & $2.3 \times 10^{6}$ & $7.9 \times 10^{6}$ & $3.5 \times 10^{6}$ & 0.50 & 230.3 \\
\hline Salmonella & Negative & Negative & Negative & Negative & & \\
\hline Clostridium & Negative & Negative & Negative & Negative & & \\
\hline
\end{tabular}

${ }^{1}$ Control without organic acids; ${ }^{2}$ Commercial product containing $10.5 \%$ fumaric acid. $8.0 \%$ malic acid and essential oils of lemon; ${ }^{3}$ Commercial product containing 10\% phosphoric acid. $10 \%$ citric acid. $10 \%$ malic acid and $20 \%$ fumaric acid; ${ }^{4} \mathrm{Commercial}$ product containing $40.5 \%$ formic acid, $13.6 \%$ phosphoric acid, $4.9 \%$ propionic acid and its salts $(23.2 \%$ calcium and $4.4 \%$ phosphorus available).

The development of the organs of the gastrointestinal tract (Table 11) did not differ by treatment $(\mathrm{P}>005)$. This finding may be related to the performance of the animals, which is related to the food consumption (energy / protein) (BIKKER et al., 1995). Because these parameters did not differ, the results were consistent, although all rations were isonitrogenous and isocaloric. Thus, the results were similar to those of Namkung et al. (2004), who supplemented the diets of weaned piglets with plant extracts and organic acids and observed no differences in the relative weights of the small intestine and colon of pigs. 
Table 11. Means of organ's weight (stomach, small intestine, large intestine and total) of weaned piglets according the treatments.

\begin{tabular}{|c|c|c|c|c|c|c|c|}
\hline \multirow[b]{2}{*}{ Treatments } & \multirow[b]{2}{*}{ Control $^{1}$} & \multicolumn{2}{|c|}{ Microencapsulated } & \multirow[b]{2}{*}{$\begin{array}{l}\text { Acid salt } \\
\text { blend }^{4}\end{array}$} & \multirow[b]{2}{*}{$\begin{array}{l}\text { General } \\
\text { average }\end{array}$} & \multirow[b]{2}{*}{$\begin{array}{c}\text { P value } \\
\%\end{array}$} & \multirow[b]{2}{*}{$\mathrm{CV} \%$} \\
\hline & & $\begin{array}{l}\text { Acid and essential } \\
\text { oils blend }^{2}\end{array}$ & Acid blend $^{3}$ & & & & \\
\hline \multicolumn{8}{|l|}{ Parameters } \\
\hline Stomach & 0.803 & 0.854 & 0.838 & 0.779 & 0.817 & 0.577 & 11.55 \\
\hline $\begin{array}{c}\text { Small } \\
\text { intestine }\end{array}$ & 4.380 & 4.531 & 4.399 & 4.294 & 4.398 & 0.791 & 10.44 \\
\hline $\begin{array}{l}\text { Large } \\
\text { intestine }\end{array}$ & 3.093 & 3.061 & 2.870 & 3.375 & 3.060 & 0.621 & 23.22 \\
\hline Total & 8.276 & 8.446 & 8.107 & 8.275 & 8.416 & 0.857 & 14.48 \\
\hline
\end{tabular}

${ }^{1}$ Control without organic acids; ${ }^{2}$ Commercial product containing $10.5 \%$ fumaric acid. $8.0 \%$ malic acid and essential oils of lemon; ${ }^{3}$ Commercial product containing $10 \%$ phosphoric acid. $10 \%$ citric acid. $10 \%$ malic acid and $20 \%$ fumaric acid; ${ }^{4}$ Commercial product containing $40.5 \%$ formic acid, $13.6 \%$ phosphoric acid, $4.9 \%$ propionic acid and its salts $(23.2 \%$ calcium and $4.4 \%$ phosphorus available).

\section{Conclusions}

Commercial blends of organic and inorganic acids effectively controlled diarrhea in the postweaning period, and this control was attributed to effects on the small and large intestine, as confirmed by higher VFA production in the cecum. Blends of microencapsulated acids are effective at lower doses compared with the blend of acid salts, and the mixture of microencapsulated organic acids and essential oils is effective at even lower doses than both of these aforementioned treatments, demonstrating the synergistic effects of these components, even at lower doses. These strategies can favor the economy of treatments and help to formulate rations that minimize the inclusion of non-nutritional additives.

\section{References}

BASSAN, J. D. L.; FLÔRES, M. L.; ANTONIAZZI, T.; BIANCHI, E.; KUTTEL, J.; TRINDADE, M. M. Controle da infecção por Salmonella Enteritidis em frangos de corte com ácidos orgânicos e mananoligosssacarídeos. Ciência Rural, Santa Maria, v. 38, n. 7, p. 1961-1965, 2008.

BIKKER, P.; KARABINAS, V.; VERSTEGEN, M. W. A.; CAMPBELL, R. G. Protein and lipid accretion in body components of growing gilts (20 to 40kilograms) as affected energy intake. Journal of Animal Science, Champaign, v. 73, n. 8, p. 2355-2363, 1995.
BLANK, R.; MOSENTHIN, R.; SAUER, W. C.; HUANG, S. Effect of fumaric acid and dietary buffering capacity on ileal and fecal amino acid digestibilities in early-weaned pigs. Journal Animal Science, Champaign, v. 77, n. 11, p. 2974-2984, 1999.

BRASIL. Ministério da Agricultura, Pecuária e Abastecimento Secretaria de Defesa Agropecuária DISPOA. Instrução Normativa $\mathrm{n}^{\circ} 62$, de 26 de agosto de 2003. Oficializa os Métodos Analíticos Oficiais para Análises Microbiológicas para Controle de Produtos de Origem Animal e Água. Diário Oficial [da] União, Brasília, 26 ago. 2003, Seção 1, p. 14.

.Ministério da Agricultura, Pecuária e Abastecimento Secretaria de Defesa Agropecuária. Portaria $n^{\circ} 126$, de 03 de novembro de 1995 . Normas de Credenciamento e Monitoramento de Laboratórios de Diagnóstico das Salmoneloses Aviárias (S. Enteritidis, S. Gallinarum, S. Pullorum e S. Typhimurium)". Diário Oficial [da] União, Brasília, 6 nov. 1995, Seção 1, p. 47.

BRAZ, D. B. Acidificantes como alternativas aos antibióticos melhoradores do desempenho de leitões na fase de creche. 2008. Dissertação (Mestrado em Ciência Animal e Pastagens) - Universidade de São Paulo, Piracicaba. Disponível em: $<$ http://wwwtesesuspbr/teses/ disponíveis/11/11139/tde-14052008-113209>. Acesso em: 27 abr. 2014.

BRAZ, D. B.; COSTA, L. B.; BERENCHTEIN, B.; TSE, M. L. P.; ALMEIDA, V. V.; MIYADA, V. S. Acidificantes como alternativa aos antimicrobianos promotores do crescimento de leitões. Archivos de Zootecnia, Córdoba, v. 60, n. 231, p. 745-756, 2011. 
CORASSA, A.; LOPES, D. C.; BELlAVER, C. Mananoligossacarídeos, ácidos orgânicos e probióticos para leitões de 21 a 49 dias de idade. Archivos de Zootecnia, Córdoba, v. 61, n. 235, p. 467-476, 2012.

CORASSA, A.; LOPES, D. C.; OSTERMANN, J. D.; SANFELICE, A. M.; TEIXEIRA, A. O.; SILVA, G. F.; PENA, S. M. Níveis de ácido fólico em dietas contendo ácido fórmico para leitões de 21 a 48 dias de idade. Revista Brasileira de Zootecnia, Viçosa, MG, v. 35, n. 2, p. 462-470, 2006.

COSTA, L. B.; LUCIANO, F. B.; MIYADA, V. S.; GOIS, F. D. Herbal extracts and organic acids as natural feed additives in pig diets. South African Journal of Animal Science, Pretoria, v. 43, n. 2, p. 181-193, 2013.

ERWIN, E. S.; MARCO, G. J.; EMERY, E. M. Volatile fatty acid analyses of blood and rumen fluid by gas chromatography. Journal of Dairy Science, Champaign, v. 44, n. 9, p. 1768-1771, 1961.

FREITAS, L. S.; LOPES, D. C.; FREITAS, A. F.; CARNEIRO, J. C.; CORASA, A.; PENA, S. M.; COSTA, L. F. Avaliação de ácidos orgânicos em dietas para leitões de 21 a 49 dias de idade. Revista Brasileira de Zootecnia, Viçosa, MG, v. 35, n. 4, p. 1711-1719, 2006.

GEBRU, E.; LEE, J. E.; SON, J. C.; YANG, S. Y.; SHIN, S. A.; KIM, B.; KIM, M. K.; PARK, S. C. Effect of probiotic-, bacteriophage-, or organic acidsupplemented feeds or fermented soybean meal on the growth performance, acute-phase response, and bacterial shedding of grower pigs challenged with Salmonella enterica serotype Typhimurium. Journal of Animal Science, Champaign, v. 88, n. 12, p. 3880-3886, 2010.

GOMES, F. E.; FONTES, D. O.; SAliBA, E. O. S.; FERREIRA, W. M.; FIALHO, E. T.; SILVA, F.C. O.; SILVA, M. A.; CORRÊA, G. S. S.; SALUM, G. M. Ácido fumárico e sua combinação com os ácidos butírico ou fórmico em dietas de leitões recém-desmamados. Arquivo Brasileiro de Medicina Veterinária e Zootecnia, Belo Horizonte, v. 59, n. 5, p. 1270-1277, 2007.

GRILLI, E.; MESSINA, M. R.; TEDESCHI, A.; PIVA, A. Feeding a microencapsulated blend of organic acids and nature identical compounds to weaning pigs improved growth performance and intestinal metabolism. Livestock Science, Amsterdam, v. 133, n. 1-3, p. 173-175, sep. 2010.

KASPROWICZ-POTOCKA, M.; FRANKIEWICZ, A.; SELWET, M.; CHILOMER, K. Effect of salts and organic acids on metabolite production and microbial parameters of piglets digestive tract. Livestock Science, Amsterdam, v. 126, n. 1-3, p. 310-313, 2009.
LI, Z.; YI, G.; YIN, J.; SUN, P.; LI, D.; KNIGHT, C. Effects of organic acids on growth performance, gastrointestinal $\mathrm{pH}$, intestinal microbial populations and immune responses of weaned pigs. Asian Australasian Journal of Animal Sciences, Seoul, v. 21, n. 2, p. 252261, 2008.

MEUNIER, J. P.; CARDOT, J. M.; GAUTHIER, P.; BEYSSAC, E.; ALRIC, M. Use of rotary fluidized-bed technology for development of sustained-release plant extracts pellets: potential application for feed additive additive delivery. Journal of Animal Science, Champaign, v. 84, n. 7, p. 1850-1859, 2006.

MICHIELS, J.; MISSOTTEN J. A.; FREMAUT, D.; DE SMET, S.; DIERICK, N. A. In vitro characterization of the antimicrobial activity of selected essential oil components and binary combinations against the pig gut flora. Animal feed Science and Technology, Amsterdam, v. 151, n. 1, p. 111-127, 2009.

MIGUEL, W. C.; TRINDADE NETO, M. A.; BERTO, D. A.; KOBASHIGAWA, E.; GANDRA, E. R. S. Suplementação de acidificantes em rações de leitões desmamados: desempenho e digestibilidade. Brazilian Journal of Veterinary Research and Animal Science, São Paulo, v. 48, n. 2, p. 141-146, 2011.

MROZ, Z. Organic acids as potential alternatives to antibiotic growth promoters for pigs. Advances in Pork Production, Alberta, v. 16, p. 169-182, 2005.

NAMKUNG, H.; LI, M.; GONG, J.; YU, H.; COTTRILL, M.; DE LANGE, C. F. M. Impact of feeding blends of organic acids and herbal extracts on growth performance, gut microbiota and digestive function in newly weaned pigs. Canadian Journal of Animal Science, Ottawa, v. 84, n. 4, p. 697-704, 2004.

OETTING, L. L.; UTIYAMA, C. E.; GIANI, P. A.; RUIZ, U. S.; MIYADA, V. S. Efeitos de extratos vegetais e antimicrobianos sobre a digestibilidade aparente, o desempenho, a morfometria dos órgãos e a histologia intestinal de leitões recém-desmamados. Revista Brasileira de Zootecnia, Viçosa, MG, v. 35, n. 4, p. 13891397, 2006.

OWUSU-ASIEDU, A.; NYACHOTI, C. M.; MARQUARDT, R. R. Response of early-weaned pigs to an enterotoxigenic Escherichia coli (K88) challenge when fed diets containing spraydried porcine plasma or pea protein isolate plus egg yolk antibody, zinc oxide, fumaric acid, or antibiotic. Journal of Animal Science, Champaign, v. 81, n. 7, p. 1709-1798, 2003.

PARTANEN, K.; MROZ, Z. Organic acids for performance enchancement in pig diets. Nutrition Research Reviews, Cambridge, v. 12, n. 1, p. 117-145, 1999. 
PASTUSZEWSKA, B.; TOMASZEWSKA-ZAREMBA, D.; BURACZEWSKA, L.; SWIECH, E.; TACIAK, M. Effects of supplementing pig diets with tryptophan and acidifier on protein digestion and deposition, and on brain serotonin concentration in young pigs. Animal Feed Science and Technology, Amsterdam, v. 132, n. 1-2, p. 49-65, 2007.

PIVA, A.; GRILLI, E.; FABBRI, L.; PIZZAMIGLIO, V.; CAMPANI, I. Free versus microencapsulated organic acids in medicated or not medicated diet for piglets. Livestock Science, Amsterdam, v. 108, n. 1-3, p. 214-217, 2007 a.

PIVA, A.; PIZZAMIGLIO, V.; MORLACCHINI, M.; TEDESCHI, M.; PIVA, G. Lipid microencapsulation allows slow release of organic acids and natural identical flavors along the swine intestine. Journal of Animal Science, Champaign, v. 85, n. 2, p. 486-493, 2007 b.

PLATEL, K.; SRINIVASAN, K. Digestive stimulant action of spices: a myth or reality? Indian Journal of Medical Research, New Delhi, v. 119, n. 5, p. 167-179, 2004.

ROSTAGNO, H. S.; ALBINO, L. F. T.; DONZELE, J. L.; GOMES, P. C.; OLIVEIRA, R. F.; LOPES, D. C.; FERREIRA, A. S.; BARRETO, S. L. T. Tabelas brasileiras para aves e suínos: composição de alimentos e exigências nutricionais. Viçosa, MG: Universidade Federal de Viçosa, 2011. 252 p.

ROTH, F. X. Ácidos orgánicos en nutrición porcina: eficacia y modo de acción. In: CURSO DE ESPECIALIZACIÓN, 11., 2000, Barcelona. Anales... Barcelona: Fundación Española para El Desarrollo de la Nutrición Animal - FEDNA, 2000. p. 169-181.

SCHURCH, A. F.; CRAMPTON, E. W.; HASKELL, S. R.; LLOYD, E. The use of chromic oxide in digestibility studies with pigs fed ad libitum in the barn. Journal of Animal Science, Champaign, v. 11, n.2, p. 261-265, 1952.

SILVA, A. M. R.; BERTO, D. A.; LIMA, G. J. M. M.; WECHSLER, F. S.; PADILHA, P. M.; CASTRO, V. S. Valor nutricional e viabilidade econômica de rações suplemantadas com maltodextrina e acidificante para leitões desmamados. Revista Brasileira de Zootecnia, Viçosa, MG, v. 37, n. 2, p. 286-295, 2008.
SILVA, N.; JUNQUEIRA, V. C. A.; SILVEIRA, N. F. A.; TANIWAKI, M. H.; SANTOS, R. F. S.; GOMES, R. A. R. Manual de métodos de análise microbiológica de alimentos e água. 4. ed. São Paulo: Varela, 2010. 624p.

SILVEIRA, H.; ALVARENGA, R. R.; RODRIGUES, V. V.; OLIVEIRA JÚNIOR, G. M.; ZANGERONIMO, M. G. Padronização de uma metodologia eficaz de determinação do $\mathrm{pH}$ do conteúdo estomacal de leitões na fase inicial. Pubvet, Londrina, v. 1, n. 8, p.1-8, 2007.

SURYANARAYANA, M. V. A. N.; SURESH, J.; RAJASEKHAR, M. V. Organic acids in swine feeding: a review. Agricultural Science Research Journals, Moorebank, v. 2, n. 9, p. 523-533, 2012.

UTIYAMA, C. E.; OETTING, L. L.; GiAnI, P. A.; RUIZ, U. S.; MIYADA, V. S. Efeitos de antimicrobianos, prebióticos, probióticos e extratos vegetais sobre a microbiota intestinal, a frequência de diarreia e o desempenho de leitões recém-desmamados. Revista Brasileira de Zootecnia, Viçosa, MG, v. 35, n. 6, p. 23592367, 2006.

VAN BEERS-SCHREURS, H. M. G.; NABUURS, M. J. A.; VELLENGA, L.; KALSBEEK-VAN DER VALK, H. J.; WENSING, T.; BREUKINK, H. J. Weaning and the weanling diet influence the villous height and crypt depth in the small intestine of pigs and alter the concentrations of short-chain fatty acids in the large intestine and blood. The Journal of Nutrition, Springfield, v. 128, n. 6, p. 947953, 1998.

VASSALO, M.; FIALHO, E. T.; OLIVEIRA, A. I. G.; TEIXEIRA, A. S.; BERTECHINI, A. G. Probióticos para leitões dos 10 aos $30 \mathrm{~kg}$ de peso vivo. Revista Brasileira de Zootecnia, Viçosa, MG, v. 26, n. 1, p. 131-138, 1997.

WEARY, D. M.; JASPERS, J.; HOTZEL, M. J. Understanding weaning distress. Applied Animal Behavior Science, Amsterdam, v. 110, n. 1, p. 24-41, 2008.

WILLAMIL, J.; CREUS, E.; PÉREZ, F. J.; MATEU, E.; ORÚE-MARTÍN, S. M. Effect of a microencapsulated feed additive of lactic and formic acid $n$ the prevalence of Salmonella in pigs arriving at the abattoir. Archives of Animal Nutrition, Montreux, v. 65, n. 6, p. 431-444, 2011. 
